\title{
Hospitality as a pivotal value in leadership: A transdisciplinary engagement with the case of Chief Albert Luthuli
}

\begin{tabular}{|c|c|}
\hline \multicolumn{2}{|c|}{$\begin{array}{l}\text { Authors: } \\
\text { Yolande Steenkamp }{ }^{1} \\
\text { Derick de Jongh }^{1}\end{array}$} \\
\hline \multicolumn{2}{|c|}{$\begin{array}{l}\text { Affiliations: } \\
{ }^{1} \text { Department of Business } \\
\text { Management, Faculty of } \\
\text { Economic and Management } \\
\text { Sciences, University of } \\
\text { Pretoria, Pretoria, } \\
\text { South Africa }\end{array}$} \\
\hline \multicolumn{2}{|c|}{$\begin{array}{l}\text { Corresponding author: } \\
\text { Yolande Steenkamp, } \\
\text { yolande.steenkamp@up. } \\
\text { ac.za }\end{array}$} \\
\hline \multicolumn{2}{|c|}{$\begin{array}{l}\text { Dates: } \\
\text { Received: } 22 \text { Apr. } 2021 \\
\text { Accepted: } 18 \text { July } 2021 \\
\text { Published: } 30 \text { Sept. } 2021\end{array}$} \\
\hline \multicolumn{2}{|c|}{$\begin{array}{l}\text { How to cite this article: } \\
\text { Steenkamp, Y. \& De Jongh, D., } \\
\text { 2021, 'Hospitality as a pivotal } \\
\text { value in leadership: A } \\
\text { transdisciplinary engagement } \\
\text { with the case of Chief Albert } \\
\text { Luthuli', HTS Teologiese } \\
\text { Studies/Theological Studies } \\
77(4), \text { a6774. https://doi. } \\
\text { org/10.4102/hts.v77i4.6774 }\end{array}$} \\
\hline \multicolumn{2}{|c|}{$\begin{array}{l}\text { Copyright: } \\
\text { ( ) 2021. The Authors. } \\
\text { Licensee: AOSIS. This wo } \\
\text { is licensed under the } \\
\text { Creative Commons } \\
\text { Attribution License. }\end{array}$} \\
\hline \multicolumn{2}{|c|}{ Read online: } \\
\hline 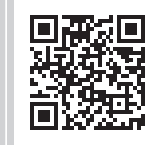 & $\begin{array}{l}\text { Scan this QR } \\
\text { code with your } \\
\text { smart phone or } \\
\text { mobile device } \\
\text { to read online. }\end{array}$ \\
\hline
\end{tabular}

This article presents hospitality as a pivotal value in the context of increasing diversity that characterises the complex relations in which leadership emerges. After reviewing the concept of Otherness in philosophy, the notion of hospitality as developed by Richard Kearney in relation to his philosophy of religion (The God Who May Be) is introduced. The case of Nobel Peace Prize Laureate Chief Albert Luthuli is then presented as a biographical leadership study from the African context to illustrate how hospitality as open response to radical Otherness may inspire collaboration and foster positive change. The article then addresses ways in which the notions of hospitality and Otherness present new opportunities to leadership studies for responding to the relational challenges of the globalised world. Amidst an increased scholarly focus on relationality and the need for relational intelligence, globalisation routinely confronts leaders and their followers with radical Otherness. Through dialogue between theology, philosophy of religion and leadership studies and by presenting a case from the African context, the article offers in print what is called for in the global context, namely an open response to the alterity of the Other that enables collaboration amidst increasing diversity.

Contribution: Proceeding from a transdisciplinary engagement, the article illustrates that leadership studies stood to benefit from dialogue with theology and philosophy of religion, which offers ways of addressing the Otherness that characterise the globalised context of leadership.

Keywords: otherness; hospitality; relationality; leadership; Richard Kearney; Albert Luthuli; biographical leadership.

\section{Introduction}

The increase in various forms of diversity calls for unprecedented skill in building relationships as globalisation and global value creation steadily pose new challenges to leadership. Consequently, the fields of economics, business management, corporate responsibility, and critical leadership have seen a steady rise in studies that include relationality as a central concept (e.g. D'Innocenzo, Mathieu \& Kukenberger 2016; Hogan \& Armstrong 2008; Kyriakidou \& Özbilgin 2006; Maak \& Pless 2006; Maessen, Van Seters \& Van Rijckevorsel 2007; Pérezts, Russon \& Painter 2020; Uhl-Bien \& Ospina 2012; Wieland 2017, 2018). By relationality, we mean both the theoretical approach that sees leadership as a socially constructed process where the relation between agents continually evolves, as per relational leadership theory (Uhl-Bien 2006), as well as the recognition that relations characterise human existence and organisations (e.g. Wieland's [2018] idea of the firm as a 'nexus of stakeholders').

The challenge of relating to individuals, processes, values, beliefs, legislation and practices radically different to one's own takes centre stage in globalised value creation. To this end, Baumann Montecinos (2019) and Wieland and Baumann Montecinos (2018, 2019) have proposed transcultural leadership as an attempt to describe effective leadership in a globalising context. Baumann Montecinos' (2019) concept of moral culture as a form of capital (cultural capital) has the important benefit of locating culture in economics, thus rendering a far more comprehensive picture of the complexity of economic realities. It is important that the cultural alterity encountered in global relationship is sufficiently appreciated; however as a premature emphasis on cultural similarities that enable cooperation, it may result in volatile relations. This article addresses this problem.

One way to describe the densities that meet agents and leaders in a globalised context is as an encounter with Otherness, a term borrowed from philosophy. By proposing radical hospitality 
as a response to Otherness encountered in global leadership contexts, this article suggests that hermeneutical competence in the face of the phenomenological experience of Otherness is a critical success factor in today's economic, social and political relations. The hermeneutical response to Otherness is argued to potentially deepen stakeholder relations whilst creating the possibility of eschatological spaces in organisations that operate in divided communities. For this, we borrow especially from philosopher Richard Kearney, whose formulation of hospitality has been deeply informed by peace efforts made by religious traditions in Northern Ireland. Following this, the article illustrates the potential of radical hospitality as a response to Otherness through a biographical leadership study of Chief Albert Luthuli, who demonstrated great commitment to hosting the Other in the exclusivist context of apartheid South Africa. For his leadership in a campaign of civil disobedience against apartheid, Chief Luthuli became the first African to be awarded the Nobel Peace Prize. In conclusion, we lay down contours for how Otherness and hospitality adds a valuable perspective amidst an increased focus on relationality in leadership studies.

The methodology is built around a deliberate inclusion of the 'Other' in dialogue with the field of leadership studies. We propose that leadership in the various sectors of politics, economics and civil society may be enriched by the contribution of philosophy and theology. Religious texts contain rich material for responding to 'the stranger in your midst', yet the disciplines of philosophy, and especially theology or religious studies are often 'othered' in academia. The article further demonstrates openness to the Other by illustrating the potential of hospitality to encourage collaboration through a biographical leadership study from Africa. The article aims to create dialogue between Africa and the West, even as Luthuli and Kearney meet as radical Others.

We position this transdisciplinary reflection as theoretically aimed at leadership studies, but refrain from selecting a specific leadership theory in order to invite dialogue from multiple approaches in the leadership field. Our own thinking however, has been decisively influenced by leadership theories to which an appreciation for relationality is already somewhat endemic (including relational leadership, servant leadership, responsible leadership, authentic leadership, transformational leadership). However, given our understanding of hospitality as a value, ethical and value-based leadership, theories may also offer particularly valuable insights into the proposed dialogue.

\section{Otherness in continental philosophy}

Referring to the most elementary level of the difference (Latin: alter) between one and another, reflections on Otherness has a long history in Philosophy, although this interest has grown significantly since the dawn of phenomenology in the first half of the 20th century. Derrida insisted that nothing can be self-definitional, so that meaning does not reside in any one concept but emerges through supplementing and cross-referencing (Rudd 2010:222). When applied to the phenomenology of Otherness, this implies that 'Self' and 'Other' stand in a dependent relation of co-construction. The encounter between subjects has a reciprocal effect because different selves derive continuous identity and meaning from it, implying a dialectic relation with some form of Otherness at the heart of all identity construction. ${ }^{1}$

Otherness as construction always involves power relations because once a person or collective has been identified as 'Other', their value is easily denied and they themselves marginalise (Staszak 2009:43; Vukasović 2018:2). Otherness is produced ('othering') by (Reinke de Buitrago 2015):

$[U]$ nderstanding and interacting with the other so as to differentiate and distance oneself from that other, with the other being an individual or a group that the self has ideas about and possibly a relation with. (pp. 87-88)

De Beauvoir (1949) introduced Otherness in order to analyse the lived body experience of women as they were being alienated ('othered') from their embodied capacities. This was further developed in postcolonial theory (Fanon 1952, 1961; Said 1978), work on sexual othering of anyone not conforming to the perceived norm (Butler 1993), and also in critical race theory (Quijano 2000; Wynter 1992), which has been growing in prominence. Staszak (2009:44) pointed out how conquered nations were historically 'othered' according to their perceived spatial marginality, so that 'We, here, are the Self; they, there, are the Other'. Finally, an apparent fascination by or appreciation of the Other often obscures the hidden agenda of the Self to assert its own identity and feelings of superiority over/against the Other.

\section{Phenomenological Otherness, ethics and the hermeneutical self}

Ricoeur (1990) reflected on Otherness in the context of what it means to be a self. By dialoguing between arguments that the self is immediately available and self-evident (the Cartesian cogito) and, on the other, claims that the self as construction is entirely relative, Ricoeur created the possibility of an ethical self through his notion of narrative identity through a hermeneutics of selfhood. His approach reflects the co-constitutive nature of self and Otherness, whilst at the same time escaping through a narrative hermeneutics, the ethical cul-de-sac, that may result from a self that can never be located.

According to Ricoeur, the ethical intention of the narrative self is fundamentally relational because the self is constituted through the Other, 'aiming at a good life lived with and for others in just institutions' (Ricoeur 1992:172). This is a

1.We are grateful to an external reviewer for reminding us that the seif/other distinction is most pertinently characteristic of the Western paradigm, both ontologically and epistemologically. It is pertinent to keep in mind that collectivistic and individualistic cultur phenomon, with 'othering' in collectivistic cultures often taking on social rather than individua dimensions. This echoes our description of Freeman and Auster's (2011) distinction between the essentialist (individualistic) and poetic (relational) self, but we are thankful for the insight that this should be stated more explicitly. 
'lived' life. A narrative identity refers to a person's ability to both attest to her/his own existence, as well as act in this world. The essence of such a self is expressed metaphysically in terms of act and potentiality rather than in terms of substance (Pellauer \& Dauenhauer 2016). Such an ethic is teleological in the sense that the human life is oriented towards the ethical aim of self-esteem, which means (Atkins n.d.):

$[B]$ eing able to attest to oneself as being the worthy subject of a good life, where 'good' is an evaluation informed not simply by one's own subjective criteria, but rather by intersubjective criteria to which one attests. (n.p.)

The Self is thus constructed in a 'world of action, lived with others', capable of having an aim 'because the teleological structure of action extends over a whole life, understood within the narrative framework' (Atkins n.d.). We will return to the importance of such a narrative framework in the next section.

\section{Richard Kearney's hermeneutics of Otherness}

Kearney's (2003:13) approach to the question of Otherness is fundamentally ethical, seeking to answer the question of how we respond to the enigma of Otherness in the form of strangers, gods, and monsters - three 'colloquial names for the experience of alterity'. Here, we will pay special attention to the figure of the stranger, as this bears relevance to Kearney's (2003) later development of hospitality:

The figure of the 'stranger' - ranging from the ancient notion of 'foreigner' (xenos) to the contemporary category of alien invader - frequently operates as a limit-experience for humans trying to identify themselves over and against others. Greeks had their 'barbarians', Romans their Etruscans, Europeans their exotic overseas 'savages'. The western myth of the frontier epitomises this, for example, when Pilgrim encounters Pequot on the shores of Massachusetts and asks 'Who is this stranger?' Not realizing, of course, that the native Pequot is asking exactly the same question of the arrivals from Plymouth. Strangers are almost always stranger to each other. (p. 3)

Kearney (2003:4) located the origin of most strangers, gods and monsters in the fractured human psyche, reflecting splits between conscious and unconscious. In this, he follows Lacan's notion that we are constituted by Otherness and never fully present to ourselves (Rudd 2010:222). As Guénoun (2015) had also pointed out, in encountering Otherness, a self (either individual or social) may be prompted to perceive Otherness in him or herself that may so unsettle the self that it projects the Otherness in terms of symbols of exotic and sublime strangeness that 'lies at the limits of the non-human'. For Kearney, such experiences present us with the choice between understanding (with the accompanying emphasis on hermeneutic engagement) or projection.

To opt for projection repudiates Othering by opting to project it onto outsiders through stereotyping and scapegoating, which Kearney (2003:4) described as evasion strategies that we use to escape the inner alterity that we find so disturbing. The willingness to understand our experience of strangeness, on the other hand, enables an encounter with the otherness in ourselves (Kearney 2003:4), a choice which Kearney explores as a way of responding to Otherness with hospitality.

Kearney aligns himself with the philosophical critique of the autonomous subject of modern metaphysics (Kosky 2003), arguing that the results of the 'modern idolatry of the ego' (Kearney 2003:229) can be seen in the injustices against the Other that are written across the pages of history. However, this does not lead him to postmodern relativism, for although the deconstruction of the self was a necessary step, the 'postmodern obsession with absolutist ideas of exteriority and otherness' (Kearney 2003:229) may render us paralysed by an Otherness that transcends us to the extent that it leaves us unable to discern between good and evil (Kosky 2003). As both these extremes 'undermine our practical understanding of ourselves-as-others' (Kearney 2003:229), Kearney echoes Ricoeur in recognising the self as a continuous act of interpretation - a hermeneutical self. This entails a perpetual crossing of boundaries between self and Other within larger narrative horizons and enables an identity that can both act in the world and take responsibility for those actions. The possibility of such a self emerges through what Kearney terms diacritical hermeneutics, on the one hand, and narrative imagination, on the other. Diacritical hermeneutics seeks to chart a third way between modern and postmodern binary oppositions. Instead of affirming the autonomous self at the expense of the Other, or infinitely inflating the Other at the expense of the self (Kosky 2003), Kearney proposes a continuous traversing of boundaries through which the self maintains contact with the Other by means of interpretation.

Kearney's attempt to offer an interpretation of difference that will make us more hospitable to the other (Thompson 2003:101-102) involves the question of how to:

[T]hink and speak of the Other on the Other's terms, that is, without reducing otherness to a reflection of the Same - while, at the same time, being able to think and speak of the Other without falling into a sort of apophatic mysticism of the ineffable. (Manoussakis 2006:xviii)

Kearney (2003) claimed that hermeneutics is able to accomplish a self-other relation that:

$[R]$ eveals a practice of ethical 'conscience' which is the other inscribed within me as an uncontainable call from beyond. And it is precisely this summons of conscience which breaks the closed circle of the ego-cogito and reminds us of our debts to others. Here the very ipseity ${ }^{2}$ of the self- expresses itself, paradoxically and marvelously, as openness to otherness. Real hospitality. (p. 81)

How might we arrive at critical discernment between an Otherness that might harm, that might heal or that requires our assistance? Here the importance of narrative emerges, for our ability to discern the appropriate response to Otherness is to be based on a practical understanding of the unique

2.With this word, Kearney refers to Ricoeur's distinction between idem and ipse as two forms of identity of the self. See Atkins (n.d.); Pellauer and Dauenhauer (2016); and Ricoeur (1990). 
situation at hand rather than on theoretical claims about universal good (Kosky 2003):

This opens a place within ethics for the narrative imagination, in that narrative transfers the ethical problem from the realm of theory to the realm of practical understanding. We make sense of the singular situations in which life is lived by telling stories, for fiction grasps the representational particularity of events. Though we might not know what evil is as such, we can tell stories that let us identify particular evils and ground action against them. (n.p.)

Kearney explores the potential of the narrative imagination by referring to the ability to construct the self by moving to the future through a reinterpretation of the past. Whilst limitexperiences from the past, such as extreme horror or sorrow, might capture the self in the past in 'pathological forms of melancholy, amnesia or repetition' (Kearney 2003:182), narrative imagination breaks through the static past to create new possibilities for the future, just as much as it enlarges the sphere of communication through its natural reaching for connection with others (Kearney 2003:182-183). In this way, engaging history through re-engaging narrative may create a dialectic 'between what is distant and what is close, what is foreign and what is familiar, between what we might call (a) the objective/universal and (b) the subjective/intersubjective attitudes to history' (Kearney 2003:183). Whilst the past is in itself Other, it is not so inaccessible to render story-telling about it impossible or immoral. On the contrary, such narrative engagement opens the possibility to heal and forgive the atrocities of the past. In personal and collective stories, we engage the past and present to create the future and in this the ethical dimensions of narrative emerges:

Consequently, the hermeneutical task of narration is one of learning to tell stories well. Narrative is not good per se; we can tell stories poorly or we can tell them well. So it is crucial that we learn to tell them well. (Gregor 2005:6)

Such a narrative imagination is balanced by the dual legs of poetics (a self-engaging in acts of semantic innovation, creating new worlds) and ethics (a self-capable of just judgement) (Kearney 2003:188). In this way, we come full circle to relationality: in creating and maintaining contact with Others through stories and interpretation, through telling and listening, we narrate and create new worlds where collaboration between the familiar and the Other becomes possible.

\section{Radical hospitality as an open response to the other}

Having laid the foundation of Otherness discourse, we can now consider radical hospitality as open response to Otherness based on Kearney's metaphor of guest and host (cf. Kearney 2011). Fully comprehending the radical nature of Kearney's (2001) notion of hospitality requires us to begin with his philosophy of religion, which he develops in The God Who May Be: A Hermeneutics of Religion. This hermeneutic and phenomenologically informed attempt to imagine God post-metaphysically centres around his wager that (Kearney 2007):
$[O]$ ne of the most telling ways in which the infinite comes to be experienced and imagined by finite minds is as possibility - that is, as the ability to be. Even, and especially, when such possibility seems impossible to us. (p. 51)

Avoiding to speak of God in terms of the two philosophical extremes of either pure being or pure non-being, Kearney (2001:29) developed a narrative description of a fundamentally relational God that is committed to a 'shared history of becoming' with humanity. This imagines vulnerability at the heart of divinity, because whether God is going to be God in human reality depends on the human response to the call of Infinite Otherness. This is not because God's existence depends on humanity, but because, if God is a 'voice calling in the desert' that invites humanity to a loving and just future, then God cannot be God for us, in relation to us, unless we respond by allowing ourselves to be transfigured through the transcendent call so that we manifest love and justice in our world.

This fundamental departure from traditional God-talk relates to hospitality in two ways. Firstly, humanity enables God to be God through ethical responses to (especially vulnerable) Others, through small acts of kindness to the widow, orphan and stranger. Secondly, Kearney translates such acts of kindness - or acts of hospitality - as an openness to the transcendence of the Other. This means that Kearney goes the revolutionary mile of speaking of human Others in the same terms of radical alterity that he uses to describe the Infinite Other, the transcendent. Similar to how God calls into time from the eternal no-time, Kearney describes the alterity of the human Other in terms of an eschatological persona - that irreducible Otherness of the human Other that is already out of my reach the moment I become aware of it. It is by radically opening to this transcendent Otherness that we can experience something of the presence of the Infinite through the alterity of the Other. The sacred narratives of various religions echo this by describing how encounters with human strangers suddenly transform into encounters with the divine.

Hospitality, therefore, emerges as an enlarging response to the radical alterity of the Other. This Otherness points to the transcendent, indescribable Otherness that is mediated through the very 'thisness' of any Other in my presence. The Other infinitely transcends me and yet is mediated through this particular, historical person here and now. Hospitality thus denotes the hermeneutically informed wager of responding as host to the strangeness of the Other, opening to the Other as host to guest and often finding oneself transfigured in the process.

Hospitality becomes especially pronounced in the face of ideological difference that often leads to tension, and this is often compounded by historical legacies of injustice and suffering. The fact that 'host' and 'enemy' share the same Latin root (hostis) hints at the fact that not all strangers are benign. Kearney's insistence on the importance of discernment sets his approach to 
hospitality apart from someone like Derrida, who maintains that any expectations and limitations on hospitality negates its purity (Gregor 2005:4). The deconstructionists therefore argue that it is precisely because we can never anticipate the nature or the actions of our guests that hospitality (always unconditional) is such a risky business. Against this, Kearney insists that our ethical responsibility to discern between good and evil must take precedence over our epistemological commitments. Diacritical hermeneutics contends that, whilst the Other genuinely transcends us (it is not merely a matter of projection, as psychoanalysis would have it [Kearney 2003:75]), the Other does not so transcend us that it completely escapes our capacity for interpretation (cf. Gregor 2005:5). We cannot open to all Strangers who knock at our door. Whilst an impossible future becomes a possibility through human responses to the call for love and justice that often comes in the form of the 'stranger at your door', here a delicate hermeneutical dance emerges between risk and ethical imperative. The choice to extend or withhold hospitality can only emerge in a narrative moving back-and-forth between self-and-other. Radical hospitality comes at a cost, no less because the wager is made without any reassurance regarding the reaction of the Other (cf. Kearney 2018b:339-340).

In 2008, Kearney founded The Guestbook Project as an international non-profit organisation with the aim to explore how, in conflicted communities, enmity could be transformed into empathy, and how cycles of violence could be overcome in imaginative moments of welcoming the stranger (Kearney 2018a:50-51). The Guestbook Project proceeds from the transformative potential of narrative as worked out in Kearney's work, creating spaces for storytelling between Others (gendered, racial, political, etc.). Similar to other reconciliation initiatives, the Guestbook Project has demonstrated how enmity may be transformed into compassion and forgiveness as enemies and strangers listen in openness to one another's stories. Thus, the two elements of diacritical hermeneutics and narrative imagination combine in the service of hospitality that remains as radical as it is practically intended for real historical circumstances.

Whilst Kearney has emphasised the role of the religious imagination in this regard, he is clear that neither religious imagination nor (even) belief in God is essential for anyone to open in hospitality to the Other (Kearney 2018b:318). His preference has been to develop this notion in dialogue with notions of the sacred because of the rich metaphors, images and stories that these provide, and in the light of his childhood memories of interreligious hospitality that attempted to heal rifts and conflict through openness to the other (cf. Kearney 2018a:21-26). The following biographical account likewise illustrates how sacred narrative greatly impacted Chief Luthuli's leadership, so that the former President Thabo Mbeki (2004:ix), for instance, recognised how Chief Luthuli's spiritual convictions enabled him to forge 'a democratic political outlook that embraced people of all colours, races and creeds as members of the human family' - real hospitality.

\section{Chief Albert Luthuli: A hospitable leader}

This section illustrates how Chief Luthuli's leadership inspired hospitality in the African National Congress (ANC) during the early days of apartheid. This does not imply that we disregard the necessary deconstruction of 'romantic notions of heroic leadership' (Carroll, Firth \& Wilson 2019) or the scholarly trend to conceptualise leading as leadership processes. In the spirit of diacritical hermeneutics, leadership studies should aspire to create a third way between either exaggerating or completely denying the role and impact of individuals in leadership. The purpose of this article is not to elevate Chief Luthuli to some quasi-messiah figure. Indeed, some perspectives from which his leadership may be analysed leave his leadership open to critique. ${ }^{3}$ Our choice for Chief Luthuli's story is a pragmatic one, aiming to illustrate a value for which the Chief had a special gift, namely hospitality to the Other. As the recently proposed moral-philosophical African theory of good leadership defined a good leader as 'one who creates, sustains and enriches communal relationships and enables others to do so' (Metz 2018:41), viewing Chief Luthuli's leadership narrative from the angle of hospitality is highly relevant to leadership studies and its increased focus on relationality.

By biographical leadership study we mean, technically, a narrative approach to Luthuli's life history in order to illustrate Chief Luthuli's capacity for openness. Through anecdotes told mostly by Luthuli himself in his autobiography, we illustrate how he as a leader related to Otherness ('life story') whilst supplementing this here and there with external sources and speeches ('life history') (cf. Bryman 2004; cf. Nkomo \& Kriek 2011:456). Our approach is narrative in that we have not attempted to write a history. We assume that the events disclosed in his autobiography or the principles espoused in his speeches reflect his own 'meaningmaking system' (Shamir, Dayan-Horesh \& Adler 2005:17), weaving together a story from the many events of his life for the dual purpose of organising these events and of communicating his ideals to his followers and effect change (cf. Ciulla 2016:189; Redekop 2016:161). As such, we offer this case as an illustration of Kearney's narrative imagination in action: the power of story to engender change by engaging the past to create a new possible world.

We begin with an insider's view of what shaped Chief Luthuli's engagement with those different from himself, of which there were a great many over the course of his lifetime. Chief Luthuli (2006:24) remarks that he has tried to adhere in his meetings with people to a sentence he remembered from

3.0ne example concerns the narrative of a 'non-racial society' that i................... in the Chief's condership of South Africans seeking their freedom. This notion, along in the Chief's ' with ideas of 'unity in diversity', as exemplified by the rainbow nation metaphor, has been problematised in our day (cf. the overview by Vorster 2017.1-2). We refrain from deconstructing these ideas here, prevalent as they are in the narrative and allow the Chief to speak on these matters in his own terms. 
Dr. Breuckner, head at the Industrial School where he taught: 'You must give a charitable interpretation to every man's actions, until you can prove that such an interpretation is unsound'. This single line, easily overlooked in his bibliography, reveals Chief Luthuli's openness to the other through his intent to accept the bona fide of whosoever he engaged with, and stands in stark contrast to the suspicion, fear and prejudice of the time.

A second reflection illustrates that the Chief considered inclusiveness and openness as superior moral values, significant given his context. The Liberal Party entered South African public affairs towards the end of the Defiance Campaign of 1952. Chief Luthuli whilst commenting on a group led by Patrick Duncan and joined by Africans, Indians and white people, who defied the law requiring permits for entry into locations, notes that this party was able to speak with much greater moral authority and commended the fact that the party preferred principle to convenience, having taken 'the unprecedented step of throwing its membership open to all races', which 'in the South African setting ... was an act of courage' (Luthuli 2006:132-133). Through this account, Chief Luthuli demonstrates the integral role of values that invite leaders to act on principle, having the moral courage to collaborate because of moral principle.

An endearing story describing a chance encounter between himself and an African police officer at a train station in Bethlehem illustrates Chief Luthuli's commitment to refrain from stereotyping the stranger. Whilst black police officers were often ostracised by the black community for being seen as conspiring with white oppressors, Chief Luthuli's (2006) deliberation of the encounter illustrates the transformative power of stepping into the shoes of the ideological Other:

I am not among those who rail against the police, but the lot of the African policeman is becoming harder every day. On the one side are his white superiors who ask him not merely to be a policeman but to be a pro-Nationalist defender of white domination - what a role for an African! On the other side are his own people ... to whom the police are, more and more, part of the machinery of oppression. His sympathies are with his people, his white superiors often goad him against them. He wants to do a worthwhile job properly, but he is used to bolster up all-white rule. His lot is unenviable - indeed, it is becoming tragic. (p. 138)

As the train left Bethlehem's station, Chief Luthuli recalled how the man (whom he now called his 'new friend') stood behind a pillar, then looked to the right and to the left, ensuring no one would see him and raised his hand in the ANC salute (Luthuli 2006:138). This moment illustrates what Kearney refers to as the trans-figurative potential of hospitality: whilst many would have scapegoated the policeman, the leader of the struggle opened up to him through an act of compassion and both were left enlarged by this narrative exchange.

An important aspect of the dynamics of Otherness during this time became visible in the growing tension within the
ANC; between the organisation at large and the so-called 'Africanists', a small but vocal group who insisted that the resistance was an Africans-only movement. They repudiated the broad South Africanism of the ANC, which favoured 'uniting all resisters to white supremacy, regardless of race' (Luthuli 2006:180). Chief Luthuli (2006:180-181) argued against this Africanist view on a matter of principle, rather than a mere means-to-an-end reasoning that would see strength in numbers against the evil of apartheid. ${ }^{4}$ Says the Chief (2006):

The emergence of cooperation between people of different race is one of the most hopeful advances of the last twelve years, not merely because it increases the impact of the resistance, but because it is the beginning of a non-racial South Africa. I believe that a racially exclusive resistance is the wrong reply to a racially exclusive oppression. It is morally the wrong reply, and it is also a demonstration of the wrong method if we think of the ideal it sets before our children. Tactically, the drawing in of our horns and the concentration of our forces may have some advantages, but in the long run it will obstruct the way to a South Africa which embraces all her citizens. (p. 181)

Whilst Chief Luthuli's hospitality caused him some unpopularity and considerable frustration, for him this was a matter of principle which he articulated in the address, 'Our vision is a democratic society':

... I personally believe that here in South Africa, with all our diversities of colour and race, we will show the world a new pattern of democracy. I think there is a challenge to us in South Africa to set a new example for the world. We can build a homogeneous South Africa on the basis not of colour but of human values. (Luthuli 1958, published in Pillay 1993:120-129 [126])

Kader Asmal (2006:xx) pointed out how Chief Luthuli understood apartheid as 'a tragic failure of imagination'. Apartheid's reduction of the human dignity of Africans was something that began in the imagination, and the only way that such a deficient imagination could be addressed was by embodying the value of respect to those who were different a kindness they themselves were refused by white supremist. 'Recovering human dignity required imagination and courage', Asmal commented (2006:xx) and this began by keeping the ANC open, so that 'Luthuli advanced this nonracial, multireligious tradition of non-violent resistance in the Defiance Campaign of 1952 and subsequent political work' (Asmal 2006:xxi).

The final episode in this biographical account illustrates both how hospitality requires the ability to imagine otherwise, as well as its power to transfigure. Following the symbolic act of defiance during which the ANC called for the burning of passes, the Chief was soon arrested. He recalls two striking memories from this time:

4.In the end, and to Chief Luthuli's regret, the ANC was compelled to act against the Africanists when the ANC Working Committee expelled two men - not for holding minority views, but because they impeded policy officially discussed and voted in by the ANC (Luthuli 2006:181). This confict eventually culmiscussed in the formation of the Pan Africanist Congress (PAC), which acted as a rival body to the ANC (Luthuli 2006:182) - a rift that Chief Luthuli remained hopeful might be healed once tempers had settled down. 
The first finds him in court, and the Chief (2006) describes the 'moving' memory he carried away from his trial as he chose to see a new reality in the multicultural gathering of spectators together in one room - a rare occasion for South Africa in the apartheid years:

The area of the court accommodating them was always thronged, and I heard later that many people had to be turned away. Apartheid prevailed in the seating arrangements, of course; but the spectators were a multiracial company all the same. There, in embryo, was a portrayal of my new South Africa, a company of men and women of goodwill, yearning to begin work on the building of a structure both permanent and real. (p. 225)

The second memory transpires as the Chief returned home to Natal by train, free because of the defence of his lawyers, and friends who had paid his fine. It was, at the time, a crime to refer to Chief Luthuli by the title 'Chief', because this title had been revoked by the Nationalist Government when Chief Luthuli became leader of the ANC in 1952. He (2006) recalls how he and his travelling partner were besieged on the train:

News that I was aboard got round. A white ticket collector helped to spread the tidings. As I moved along the crowded corridor he called out: 'Make way, move out of the way. Don't you know this is Chief Luthuli? Don't you know your own leader? Stand out of the way!' (p. 226)

In the first memory, we see the resolve of a leader to prioritise seeing his vision of restored human dignity in circumstances that most would have called the triumph of evil and the denial of hope. In this we see, the importance of the imagination as the ability to hold a vision (of reconciliation) that propels the individual to action in the present (responding to Otherness with hospitality). In the second memory, we see the capacity of such leaders to capture the imagination, even of the 'enemy', and consequently bring about (impossible) change.

\section{Hospitality: An invitation to leadership studies}

Hospitality has not received much scholarly attention in leadership studies. ${ }^{5}$ Our proposal of hospitality as important value in leadership theory is situated in the growing impact of relationality in leadership studies in response to increasing levels of complexity (cultural, social, economic diversity) that face leadership contexts. This article contributes to the field by suggesting hospitality as a way through which organisations may engage with the radical Otherness that they routinely encounter during global, multisector, and/or inter-organisational collaboration.

Before coming to hospitality, let us consider a number of leadership theories or approaches that have in some way, through emphasising relational approaches, attempted to

5.Leadership studies usually consider hospitality only with reference to the hospitality industry, for example, Brownell (2010), Koyuncu et al. (2014), Carter and Baghurst (2014), Wu et al. (2013) and Setiawan et al. (2020). An exception is Maier and Tavanti's (2016) focus on hospitality as a value, although mostly not in Maier and Tavanti's (2016
a leadership context. address the complexity referred to here. Painter-Morland (2008), for example, has pointed out how the process of defining one's values is always relational. Relationality is important in allowing one to act in a particular context, as boundaries of the self are never constructed in isolation, but presupposes relation to an 'other' that calls for shared values in order to live in community (Painter-Morland 2008).

Relationality has also emerged as a guiding principle in the responsible leadership field. Patzer, Voegtlin and Scherer (2018) distinguished between instrumental and integrative responsible leadership styles. Whereas instrumental responsible leadership seems to emphasise leadership as a means to an end, the integrative style regards it as an end in itself, emphasising the responsibility of leaders to create norms and values that will lead to the intended outcome of societal transformation. According to Maak, Pless and Voegtlin (2016:469-471), integrative responsible leadership styles are characterised by a high degree of interconnectedness, spanning of boundaries, and a proactive and inclusive approach of all legitimate stakeholders. Voegtlin's inquiry (2016:591-592) into responsibility has likewise found that responsible leadership 'will only be successful if it can foster collective action amongst those who share responsibility' (Voegtlin 2016:588), pointing to the crucial notion of dialogue with stakeholders and collective problem solving.

Another significant contribution in this regard points to the relational nature of values. Freeman and Auster (2011:15-23) have moved away from an individualist approach to appreciate that the values of responsible leadership emerge within a dynamic interplay of self-Other relations that include both the individual and collective past that is directed by aspirations for the future (echoing Kearney's narrative hermeneutics). Their distinction between the essentialist and poetic self illustrates that the complexity of values cannot be appreciated without reconsidering our understanding of the self in light of the dynamic relationality that creates it. Determining what those values are to which we strive to be authentic requires an enlarged view of the self that takes into account the interrelation of our past and our aspirations for the future amidst our relationships with others (Freeman \& Auster 2011:19). As such, they suggest that the 'essentialist self' be amended by the 'poetic self', which as the intersection of these dynamics (values, past, connections to others and aspirations), can be seen as a 'project of self-creation' in community over against the static view of the essentialist self (Freeman \& Auster 2011:20). Here we come extremely close to the narrative hermeneutics that was, as seen above, illustrated in Kearney's development of hospitality.

Transcultural dimensions of relationality in leadership is perhaps one of the most significant aspects to consider. We have already referred to the contributions by Wieland and Baumann Montecinos in this regard in the context of relational economics and relational leadership (see introduction). Responsible leadership approaches have also emphasised this point. In their Responsible Leadership: Realism and Romanticism, Kempster and Carol (2016) offer 
10 propositions that they see as shaping the developmental trajectory of responsible leadership. Their fifth proposition in this regard is that responsible leadership be '... sensitive to global intercultural sensitivity', 'a global citizen orientation and a call to cosmopolitanism', as well as the 'notion of "worldly" leadership' (Kempster \& Carol 2016:5). Through this proposition, the authors aim to address the question of what it means to lead responsibly in a context characterised by many global tensions in a dispersed, diverse and distributed world.

\section{Hospitality as 'response': A pivotal value in relational thinking}

Our suggestion of hospitality as a pivotal value finds its context in this fifth proposition. Indeed we hold that attempting to create a 'global citizen orientation' without the necessary attention to the extent of Otherness that characterises the meeting of different cultures as they attempt to collaborate, will result in volatile relationships that may break apart easily and, even worse, result in conflict. As such, the question of leading responsibly in a world of increasing Otherness must entail response to the Other. Hospitality as value, framed within a relational understanding of personhood (along the lines of Ricoeur, Kearney and Freeman and Auster), addresses the central question of how to deal with the radical Otherness that organisations face on many fronts as they attempt to engage in complex collaboration.

What would be the contours of hospitality within a leadership context? Here, we can offer only preliminary suggestions that we invite the disciplines to engage with and research:

- There will be story. The transformative power of narrative to foster understanding and resolve conflict has been demonstrated beyond question. To act as host to a stranger is to open to a story different from one's own and be enlarged in the process. A narrative imagination certainly formed the foundation for Chief Luthuli's own hospitable leadership. The title of his autobiography, Let My People Go, reflects the calling he felt to lead his people in a modern-day exodus to a future that included life and justice for all South Africans.

- There will be discernment. Ethical obligations to stakeholders, the environment and anybody who may be impacted by collaboration are important factors in deciding whether to respond in openness to forms of Otherness that appear as possibly harmful. We saw this unfold in the internal battle that played out between the Africanist faction and the larger, more inclusive part of the ANC. Discernment in this case resided in the Chief's moral choice to embody in the ANC the hospitality that was sorely lacking in Afrikaner nationalist politics.

- It will be dynamic. Accepting hospitality as value will require a commitment to an ongoing dynamic process of interpretation and reinterpretation, telling and retelling stories. Hospitality is not static. New stories develop as new relations continuality reinvent themselves. This will require openness to learning. A reading of Chief Luthuli's speeches and autobiography shows a delicate balance between maintaining a strong, stable vision for a desired future of inclusivity, whilst making many changes along the way in terms of strategy, although guided by a moral commitment to peaceful resistance.

- It is a matter of identity. Selves continue being forged in the co-existence and inter-weaving of narrative identities. This is true as much for individuals as for organisations and cultures. Engaging Otherness entails a redefinition - an enlargement - of self. Perhaps the person of Luthuli is the best illustration of this, because he came to embody a spaciousness that pointed ahead to a South Africa that would make space for all her children. The failure of the nationalist government to thwart the impact of such an enlarged self on the nation at large is seen in the train scene described above.

\section{Creating eschatological spaces}

Borrowed from the field of Systematic Theology, the term 'eschatological' is reinterpreted here in a non-religious sense to refer to relational spaces between Others that have been brought together by employment and or global relations that might otherwise not have shared such spaces. This might refer to increased cultural diversity in multinational corporations or international multisector partnerships to address the UN Sustainable Development Goals (SDGs), for example. Very often, however, this takes place on a more conflicted level, and here we offer the South African context with its history of segregation as an example. As a result of legislative measures such as Employment Equity, Affirmative Action and Broad Based Black Economic Empowerment (BBBEE) that attempt to address structural injustices of the past, South African places of work display great racial, gender and cultural diversity that is not reflected to the same extent in other areas of the South African society. Whilst recreational and religious spaces, for instance, continue to fall apart across racial divides, even more than two decades following the end of apartheid, individuals find themselves in occupational contexts that confront them with layered Otherness. Apart from the more obvious forms of racial and gender diversity, colleagues also represent to each other the horrors of the past. These are the spaces calling for relational intelligence (cf. Pless \& Maak 2005) and for leaders with hermeneutical skill. Importantly, these are also the spaces presenting employers with opportunities for constructing alternative, healing futures - opportunities that are often not available to those sectors of society that perpetuate division through their preference for homogeneity.

This draws a line through the philosophy that the 'one and only one social responsibility of business' is 'to use its resources and engage in activities designed to increase its profits so long as it ... engages in open and free competition without deception or fraud' (Friedman 1970). Instead, this line of thinking espouses an enlarged understanding of business responsibility to include obligations to society 
overall. There is an increasing expectation of business leaders to address economic, social justice and environmental problems in the contexts where their organisations function (see Mirvis, Steenkamp \& De Jongh 2021). Along the same vein, we would contend that business organisations are uniquely positioned to address societal wounds and contribute to reconciliation of communities who have historically borne the burden of Othering. In turn, organisations only stand to benefit from equipping their employees to resolve conflict and increase successful collaboration in the context of diversity.

\section{Conclusion}

This transdisciplinary reflection has framed radical hospitality against the background of the philosophical concept of Otherness, defining hospitality as an open response to the Other. In the context of globalisation, organisations face Otherness through many forms of diversity - cultural, social, economic, and gender. Having offered a biographical leadership study of Chief Albert Luthuli, it has illustrated the potential of hospitality to encourage collaboration where agents are faced with complex forms of Otherness. Our methodological preference for transdisciplinarity and dialogue between western and African perspectives reflects on our commitment to the crossing of pathways, the meeting of Others. We suggest hospitality as a pivotal value in leadership studies and argue that this is specifically pronounced in theories that give a central place to relationality.

\section{Acknowledgements Competing interests}

The authors declare that they have no financial or personal relationships that may have inappropriately influenced them in writing this article.

\section{Authors' contributions}

Y.S. conceived of the presented idea and wrote the initial version (a conference paper). D.d.J. and Y.S. worked together on designing the theoretical scope. D.d.J. provided feedback for revision, which Y.S. applied.

\section{Ethical considerations}

This article followed all ethical standards for research without direct contact with human or animal subjects.

\section{Funding information}

This research received no specific grant from any funding agency in the public, commercial, or not-for-profit sectors.

\section{Data availability}

Data sharing is not applicable to this article as no new data were created or analysed in this study.

\section{Disclaimer}

The views and opinions expressed in this article are those of the authors and do not necessarily reflect the official policy or position of any affiliated agency of the authors.

\section{Reference}

Asmal, K., 2006, 'Introduction', in A. Luthuli (ed.), Let my people go: The autobiography of Albert Luthuli Nobel Peace Prize winner, pp. xiii-xxiii, Tafelberg / Houghton: Mafube Publishing, Cape Town.

Atkins, K., n.d., 'Paul Ricoeur (1913-2005)', in J. Fieser \& B. Dowden (eds.), The internet encyclopedia of philosophy: A peer-reviewed academic resource, viewed 30 December 2019, from https://www.iep.utm.edu/ricoeur/.

Baumann Montecinos, J., 2019, 'Moralkapital und wirtschaftliche Performance: Informelle Institutionen, Kooperation, Transkulturalität', Dissertation Universität Hohenheim, Studien zur Ethik der Transaktion, Springer Gabler, Wiesbaden. https://doi.org/10.1007/978-3-658-26474-1

Brownell, J., 2010, 'Leadership in the service of hospitality', Cornell Hospitality Quarterly 51(3), 363-378. https://doi.org/10.1177/1938965510368651

Bryman, A., 2004, Social research methods, 2nd edn., Oxford University Press, New York, NY.

Butler, J., 1993, Bodies that matter: On the discursive limits of sex, Routledge, New York NY.

Carroll, B., Firth, J. \& Wilson, S., 2019, 'Introduction', in C. Brigid, J. Firth \& S. Wilson (eds.), After leadership, pp. 1-15, Routledge, New York, NY.

Carter, D. \& Baghurst, T., 2014, 'The influence of servant leadership on restaurant employee engagement', Journal of Business Ethics 124(3), 453-464. https://doi. org/10.1007/s10551-013-1882-0

Ciulla, J.B., 2016, 'Searching for Mandela: The insights of biographical research', Leadership 12(2), 186-197. https://doi.org/10.1177/1742715014550541

De Beauvoir, S., 1949, Le deuxi 'eme sexe, Gallimard, Paris.

D'Innocenzo, L., Mathieu, J.E. \& Kukenberger, M.R., 2016, 'A meta-analysis of different forms of shared leadership-team performance relations', Journal of Management 42(7), 1964-1991. https://doi.org/10.1177/0149206314525205

Fanon, F., 1952, Black skin, white masks, transl. C.L. Markmann, Grove Press, New York, NY.

Fanon, F., 1961, The wretched of the earth, transl. C. Farrington, Grove Weidenfeld, New York, NY.

Freeman, R.E. \& Auster, E.R., 2011, 'Values, authenticity, and responsible leadership', Journal of Business Ethics 98, 15-23. https://doi.org/10.1007/978-94-0073995-6_3

Friedman, M., 1970, 'The social responsibility of business is to increase its profits', New York Times, pp. 32-33, 122-124, 13 September.

Gregor, B., 2005, Book review: Strangers, Gods and monsters: Interpreting otherness, R. Kearney (ed.), Routledge, London, viewed 30 December 2019, from https:// commons.pacificu.edu/eip/vol6/iss1/12/.

Guénoun, T., 2015, 'The character as a figure of otherness that exists in the self', Recherches en Psychanalyse 19(1), 50-58.

Hogan, J.E. \& Armstrong, G., 2008, 'Toward a resource-based theory of business exchange relationships: The role of relational asset value', Journal of Business-toBusiness Marketing 8(4), 3-28. https://doi.org/10.1300/J033v08n04_02

Kearney, R., 2001, The God who may be: A hermeneutics of religion, Indiana Series in the Philosophy of Religion, Indiana University Press, Bloomington, IN.

Kearney, R., 2003, Strangers, gods and monsters: Interpreting otherness, Routledge, London.

Kearney, R., 2007, 'Re-imagining God', in J.D. Caputo \& M.J. Scanlon (eds.), Transcendence and beyond: A postmodern inquiry, pp. 51-65, Indiana University Transcendence and beyonc
Press, Bloomington, IN.

Kearney, R., 2011, Anatheism: Returning to God after God, Columbia University Press, New York, NY.

Kearney, R., 2018, 'Where I speak from: A short intellectual autobiography', in D.P. Veldsman \& Y. Steenkamp (eds.), Debating Otherness with Richard Kearney: Perspectives from South Africa, pp. 31-62, AOSIS, Cape Town. https://doi. org/10.4102/aosis.2018.BK94.02

Kearney, R., Veldsman, D.P. \& Steenkamp, Y., 2018b, 'Across oceans: A conversation on Otherness, hospitality and welcoming a strange God', in D.P. Veldsman \& Y. Steenkamp (eds.), Debating Otherness with Richard Kearney: Perspectives from South Africa, pp. 307-342, AOSIS, Cape Town. https://doi.org/10.4102/ aosis.2018.BK94.15

Kempster, S. \& Carroll, B., 2016, 'Introduction: Responsible leadership: Realism and romanticism', in S. Kempster \& B. Carroll (eds.), Responsible leadership: Realism and romanticism, Routledge Studies in Leadership Research, pp. 1-20, Routledge, London.

Kosky, J.L., 2003, Book review: Strangers, gods and monsters: Interpreting otherness, R. Kearney (ed.), Routledge, London, viewed 30 December 2019, from https:// ndpr.nd.edu/news/strangers-gods-and-monsters/.

Koyuncu, M., Burke, R.J., Astakhova, M., Eren, D. \& Cetin, H., 2014, 'Servant leadership and perceptions of service quality provided by front-line service workers in hotels in Turkey: Achieving competitive advantage', International Journal of Contemporary Hospitality Management 26(7), 1083-1099. https://doi. org/10.1108/IJCHM-06-2013-0238 
Kyriakidou, O. \& Özbilgin, M.F. (eds.), 2006, Relational perspectives in organizational studies: A research companion, Edward Elgar, Cheltenham. https://doi. studies: A research companic
org/10.4337/9781781950548

Luthuli, A., 1958, 'Our vision is a democratic society, 1958, address to a meeting organised by the South African Congress of Democrats', in G.J. Pillay (ed.), Albert Lutuli vol. 1: Voices of liberation, pp. 120-129, HSRC Publishers, Pretoria.

Luthuli, A., 2006, Let my people go: The autobiography of Albert Luthuli Nobel Peace Prize winner, Tafelberg / Houghton: Mafube Publishing, Cape Town.

Maak, T. \& Pless, N.M., 2006, 'Responsible leadership in a stakeholder society - A relational perspective', Journal of Business Ethics 66, 99-115.

Maak, T., Pless, N.M. \& Voegtlin, C., 2016, 'Business statesman or shareholder advocate? CEO responsible leadership styles and the micro-foundations of political CSR', Journal of Management Studies 53(3), 463-493. https://doi. org/10.1111/joms.12195

Maessen, R., Van Seters, P. \& Van Rijckevorsel, E., 2007, 'Circles of stakeholders: Towards a relational theory of Corporate Social Responsibility', International Towards a relational theory of Corporate Social Responsibility', International
Journal of Business Governance and Ethics 3(1), 77-94. https://doi.org/10.1504/ Journal of Business
IJBGE.2007.011935

Maier, T.A. \& Tavanti, M., 2016, 'Introduction: Sacred hospitality leadership: Values centered perspectives and practices', Vincentian Heritage Journal 22(1),

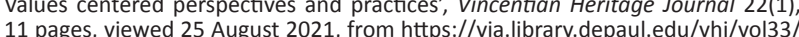
11 pages,
iss $1 / 2 \%$.

Manoussakis, J.P., 2006, 'Introduction', in J.P. Manoussakis (ed.), After God: Richard Kearney and the religious turn in continental philosophy, Perspectives in Continental Philosophy 49, pp. xv-xx, 389, Fordham University Press, New York, NY.

Mbeki, T., 2004, 'Address at the launch of the Luthuli Legacy Project', Reprinted pages in A. Luthuli (2006), Let my people go: The autobiography of Albert Luthuli, Nobel Peace Prize winner, pp. vii-xii, Tafelberg / Houghton: Mafube Publishing, Cape Town, viewed 30 May 2018, from http://m.polity.org.za/article/mbeki-unveilingof-luthuli-legacy-project-21082004-2004-08-21.

Metz, T., 2018, 'An African theory of good leadership' in J. Wieland \& J. Baumann Montecinos (eds.), Sub-Saharan perspectives on transcultural leadership, Transcultural Management Series 3, pp. 41-63, Metropolis-Verlag, Marburg.

Mirvis, P., Steenkamp, Y. \& De Jongh, D., 2021, 'Responsible leadership in context: Four frames and two nations', in T. Maak \& N. Pless (eds.), Responsible leadership, 2nd edn., Routledge, London.

Nkomo, S.M. \& Kriek, D., 2011, 'Leading organizational change in the "new" South Africa', Journal of Occupational and Organizational Psychology 84, 453-470.

Painter-Morland, M., 2008, Business ethics as practice, Cambridge University Press, Cambridge.

Patzer, M., Voegtlin, C. \& Scherer, A.G., 2018, 'The normative justification of integrative stakeholder engagement: A Habermasian view on responsible leadership', Business Ethics Quarterly 28(3), 325-354. https://doi.org/10.1017/ beq. 2017.33

Pellauer, D. \& Dauenhauer, B., 2016, 'Paul Ricoeur', in E.N. Zalta (ed.), The Stanford Encyclopedia of Philosophy, Winter 2016 edn., viewed 24 November 2019, from https://plato.stanford.edu/archives/win2016/entries/ricoeur/.

Pérezts, M., Russon, J.-A. \& Painter, M., 2020, 'This time from Africa: Developing a relational approach to values-driven leadership', Journal of Business Ethics 161 731-748. https://doi.org/10.1007/s10551-019-04343-0

Pillay, G.J., 1993, Albert Lutuli vol. 1: Voices of liberation, HSRC Publishers, Pretoria.

Pless, N.M. \& Maak, T., 2005, 'Relational intelligence for leading responsibly in a connected world', Academy of Management Proceedings 2005(1), 1-6. https:// doi.org/10.5465/ambpp.2005.18783524

Quijano, A., 2000, 'Coloniality of power, Eurocentrism, and Latin America', Neplanta: Views from the South 1(3), 533-580. https://doi.org/10.1177/02685809000 15002005
Redekop, B.W., 2016, Embodying the story: Theodore Roosevelt's conservation leadership', Leadership 12(2), 159-185.

Reinke de Buitrago, S., 2015, 'Self-other constructions, difference and threat: US and Arab "othering" of Iran', in E. Monier (ed.), Regional insecurity after the Arab uprising, pp. 85-106, Palgrave Macmillan, Basingstoke. https://doi. org/10.1057/9781137503978 5

Ricoeur, P., 1990, Oneself as another, transl. K. Blamey, University of Chicago Press, Chicago, IL.

Rudd, D., 2010, 'Other/otherness', in D. Rudd (ed.), The Routledge companion to children's literature, p. 222, Routledge, London.

Said, E.W., 1978, Orientalism, Pantheon Books, New York, NY.

Setiawan, R., Eliyana, A., Suryani, T. \& Osito, L.O., 2020, 'World-class hospitality management in tourism strategy: The implementation of servant leadership' Talent Development \& Excellence 12(3), 3122-3128.

Shamir, B., Dayan-Horesh, H. \& Adler, D., 2005, 'Leading by biography: Towards a lifestory approach to the study of leadership', Leadership 1(1), 13-29. https://doi. org/10.1177/1742715005049348

Staszak, J.-F., 2009, 'Other/otherness', in R. Kitchin \& N. Thrift (eds.), Internationa encyclopedia of human geography: A 12-volume set, pp. 43-47, Elsevier Science, Oxford.

Thompson, C.L., 2003, 'Must, or may, God be the God who may be?' Review of Kearney, R., 2001, On stories. Routledge, London; Kearney, R., 2002, The God who may be: A hermeneutics of religion, Routledge, London; Kearney, R., 2002 Strangers, gods, and monsters: ideas of otherness, Routledge, London, Journal for Strangers, gods, and monsters: ideas of otherne
Cultural and Religious Theory 4/3, 100-107.

Uhl-Bien, M., 2006, 'Relational leadership theory: Exploring the social processes of leadership and organising', The Leadership Quarterly 17(6), 654-676. https://doi. org/10.1016/j.leaqua.2006.10.007

Uhl-Bien, M. \& Ospina, S., 2012, Advancing relational leadership research: A dialogue among perspectives. Leadership horizons, Information Age Publishing, Charlotte, NC

Voegtlin, C., 2016, 'What does it mean to be responsible? Addressing the missing responsibility dimension in ethical leadership research', Leadership 12(5), 581-608. https://doi.org/10.1177/1742715015578936

Vorster, N., 2017, 'Reformed theology and "decolonised" identity: Finding a grammar for peaceful coexistence', HTS Teologiese Studies/Theological Studies 74(4), article \# 4915. https://doi.org/10.4102/hts.v74i4.4915

Vukasović, D., 2018, 'European union and otherness: The case of Balkans', Sprawy Narodowościowe Seria nowa / Nationalities Affairs New series 50, 1-12. https:// doi.org/10.11649/sn.1626

Wieland, J., 2017, 'Relationale Führung und intersektorale Governance', in M Lehmann \& M. Tyrelll (eds.), Komplexe Freiheit: Wie ist Demokratie möglich?, Komplexität und Kontingenz, pp. 237-257, Springer VS, Wiesbaden.

Wieland, J., 2018, Relational Economics. Ökonomische Theorie der Governance wirtschaftlicher Transaktionen, Metropolis, Marburg.

Wieland, J. \& Baumann Montecinos, J., 2018, 'Transculturality and global value creation', in J. Wieland \& J. Baumann Montecinos (eds.), Sub-Saharan perspectives on transcultural leadership, pp. 17-39, Transcultural Management Series 3 Metropolis-Verlag, Marburg.

Wieland, J. \& Baumann Montecinos, J. (eds.), 2019, Transcultural leadership and transcultural competence, Transcultural Management Series 2, MetropolisVerlag, Marburg.

Wu, L.-Z., Tse, E.C.-Y., Fu, P., Kwan, H.K. \& Lu, J., 2013, 'The impact of servant leadership on hotel employees' "Servant Behavior"', Cornell Hospitality Quarterly 54(4), 383-395. https://doi.org/10.1177/1938965513482519

Wynter, S., 1992, Do not call us 'negros': How 'multicultural' textbooks perpetuate racism, Aspire Books, San Francisco, CA. 